\title{
Iodine content in bulk tank milk samples in relation to dairy farm size
}

\author{
Lenka Vorlová1, Lucia Hodulová1, Ivana Borkovcován ${ }^{1}$, Hana Přidalová1, Romana \\ Kostrhounová ${ }^{1}$, Marcela Klimešová-Vyletělová ${ }^{2}$ Květoslava Šustová ${ }^{3}$ \\ ${ }^{1}$ University of Veterinary and Pharmaceutical Sciences Brno, Faculty of Veterinary Hygiene and Ecology, \\ Department of Milk Hygiene and Technology, Brno, Czech Republic \\ ${ }^{2}$ Dairy Research Institute, Ltd., Prague, Czech Republic \\ ${ }^{3}$ Mendel University, Faculty of Agronomy, Department of Food Technology, Brno, Czech Republic
}

Received March 5, 2014

Accepted July 23, 2014

\begin{abstract}
The aim of this study was to compare the iodine content in raw milk from organic and conventional dairy farms of different sizes. Milk samples were collected between 2012 and 2013, and the iodine content was determined by a Sandell-Kolthoff reaction after dry alkaline digestion of the milk samples. Comparing the iodine content in raw milk samples from small sized dairy farms $(116.76 \pm 46.29 \mu \mathrm{g} / \mathrm{l})$ and large sized dairy farms $(173.70 \pm 35.42 \mu \mathrm{g} / \mathrm{l})$, a significant difference in iodine content was observed $(P \leq 0.05)$. The lowest values were found in small and medium dairy farms, $45.30 \mu \mathrm{g} / 1$ and $40.46 \mu \mathrm{g} / \mathrm{l}$, respectively. High variability $(112.92 \pm$ $94.74 \mu \mathrm{g} / \mathrm{l})$ in the iodine content was detected in raw milk from medium sized dairy farms. When considering milk samples from organic dairy farms $(119.29 \mu \mathrm{g} / 1 \pm 40.37)$ vs. conventional dairy farms $(136.55 \mu \mathrm{g} / 1 \pm 42.91)$, no significant difference was detected. These results indicate higher iodine content in milk from large dairy farms regardless of conventional or organic farming methods.
\end{abstract}

Iodine concentration, raw bovine milk, conventional and organic dairy farms

Iodine saturation is a topic discussed worldwide and the Czech Republic belongs among countries with iodine deficiency. The iodine content changed in the last decades depending on iodine supplementation, with milk and dairy products being among the best sources of iodine. The optimal iodine saturation of the world's population is a complex issue. Principally, saturation is insufficient, which leads to related diseases. From 2 to 2.2 billion of inhabitants suffer from insufficient iodine intake. Serious iodine deficiencies, due to its necessity for the production of thyroid gland hormones, lead to permanent changes in most of the population and result in serious disorders. However, even slight deficiency during pregnancy and childhood causes disorders in body development, of which the most important is the myelin sheath that is connected with neurological diseases. In some parts of the world, however, the number of people with too high iodine intake is increasing simultaneously, which is also connected with the occurrence of diseases, such as hyperthyreosis and autoimmune thyroiditis (Zamrazil 2013).

The primary reason for the initiation of the testing of dietary iodine exposure from 1998 is the fact that the Czech Republic due to its geographical location and geological conditions has been recognized as a country with iodine deficiency.

The decisive factor for the iodine content in an organism is its intake from the daily diet. Throughout a long-term research, milk and yogurts took up the primary place as the dietary source of iodine for the whole population in the Czech Republic. However, a disadvantage of milk is its high variability of the iodine content ( ̌́ehůřková and Ruprich 2013).

In the first half of the last century, milk was not among the important sources of iodine in the Czech Republic. In 1988-1996 the absence of iodine supplementation in the basal

Address for correspondence:

MVDr. Lucia Hodulová

Department of Milk Hygiene and Technology

Faculty of Veterinary Hygiene and Ecology

University of Veterinary and Pharmaceutical Sciences Brno

Palackého tř. 1/3, 61242 Brno, Czech Republic

Phone: + 420608902140

E-mail: hoduloval@vfu.cz

http://www.vfu.cz/acta-vet/actavet.htm 
diet led to a decrease of the mean milk iodine content of $30 \mu \mathrm{g} / \mathrm{l}$. Iodine content in milk markedly increased from 1997 thanks to iodine supplementation primarily on prosperous factory farm swith high production dairy cows. After 2000, iodine concentration in milk rapidly increased to $310 \mu \mathrm{g} / \mathrm{l}$ in 2003 and continued to increase till 2010 to the mean concentration of $490 \mu \mathrm{g} / \mathrm{l}$ of milk. During 2011-2012 there was a graduate decrease to $402 \mu \mathrm{g} / \mathrm{l}$, and the median reached $267 \mu \mathrm{g} / \mathrm{l}$; in 2012 the mean value was $360 \mu \mathrm{g} / \mathrm{l}$, and the median was $235 \mu \mathrm{g} / \mathrm{l}$ (Kroupová et al. 2013). This decreasing trend is in accordance with the Commission Regulation (EC) No. 1459/2005 which determines the maximum content of iodine in the complete feed dose with a moisture content of $12 \%$ per $5 \mathrm{mg} / \mathrm{kg}$. The optimum iodine content in milk was calculated to be about 100-200 $\mu \mathrm{g} / \mathrm{l}$. The optimum estimated from the viewpoint of dietary exposure corresponding to the EU provision is $200 \mu \mathrm{g} / 1$ ( ̌̌ehůr̆ková and Ruprich 2013).

Correlation between the iodine content in milk and iodine intake by human population was described by Kursa et al. (2005). The mean iodine concentration in a group of 226 bulk samples from different localities of the Czech Republic was $310 \mu \mathrm{g} / \mathrm{l}$. The value was $2.5 \times$ higher than the findings detected before supplementation which was initiated between 1997-1999, and was higher than the current European standard. Iodine concentration in milk corresponded to the dairy cows' exposure to this trace element. Serious iodine deficiency in fodder uncorrected by feed supplements, was found in $4.0 \%$ of milk samples with values $<20 \mu \mathrm{g} / \mathrm{l}$. Iodine milk concentrations above $500 \mu \mathrm{g} / \mathrm{l}$ were detected on $16.8 \%$ farms.

In another study (Trávníček et al. 2006), iodine concentration exceeding $500 \mu \mathrm{g} / \mathrm{l}$ of milk was determined for $35.7 \%$ dairy farms, which indicates an increasing trend of iodine content in milk. The milk samples showed local and regional differences in the iodine content, and the values during the winter period were higher than in the summer period.

Based on these results, it is obvious that solution of iodine deficiency is a dynamic process. Milk is a very questionable source of iodine because of the variability determined for iodine concentration in samples ( ̌̉ehůr̆ková and Ruprich 2013). Importantly, iodine content in milk has currently stabilized and decreased (Ryšavá and Kříž 2013). Thus, permanent systematic testing of iodine concentration in bovine milk from factory dairy farms as well from small dairy farms is necessary.

The aim of this study was to compare the iodine content in raw milk from organic and conventional dairy farms of different sizes, and to determine the current iodine content in raw bovine milk from dairy farms located in the Czech Republic.

\section{Materials and Methods}

Bulk tank milk samples (BTM) were taken during 2012 and 2013 from 19 dairy farms in the different regions of the Czech Republic, including 7 organic dairy farms. Organic dairy farms were different in size, ranging from 23 to 350 dairy cows. The breed representation was Holstein Friesian cattle and their cross-breeds, Czech Fleckvieh cattle and their cross-breeds, Jersey and Montbeliarde.

Conventional farms were divided into 3 groups according to the herd size: small $(n=4)$ with $15-90$ dairy cows, medium $(n=4)$ with 180-407 dairy cows, and large $(n=4)$ with 495-710 dairy cows including the Holstein Friesian cattle and their cross-breeds, Czech Fleckvieh cattle their cross-breeds, Jersey and Montbeliarde. None of the conventional farms declared the use of feed supplemented with iodine. On large conventional farms and on 2 medium farms, brewers' grain was used for feeding at the amount of $5 \mathrm{~kg}$ in daily diet. Dairy cows from organic farming were on pasture from April to November. Pasture in conventional farming was available only in half of the small and medium dairy farms. Iodophor teat disinfectants post-milking were used on all types of farm.

The samples of BTM obtained from different dairy farms in the Czech Republic were kept under cold storage conditions in the laboratories of the Department of Milk Hygiene and Technology, and they were chilled and kept at the temperature of $-18^{\circ} \mathrm{C}$ till the analysis.

The iodine concentration was determined by Sandell-Kolthoff method based on the $\mathrm{Ce}^{(\mathrm{IV})} / \mathrm{As}^{(\mathrm{III})}$ redox reaction, which is influenced by the amount of iodine present. The reaction was stopped by the addition of brucine, and the intensity of reddish colour of the resulting adduct was evaluated by spectrophotometry at $405 \mathrm{~nm}$. By this method total iodine content was assessed, for both inorganic and organic protein-bound forms. The limit of detection was $15 \mu \mathrm{g} / \mathrm{kg}$. 
Measured values were processed with statistical software UNISTAT ${ }^{\circledR}$, Version 6.0.07 and Microsoft Excel 2007. Statistical processing of data included mean, standard error of mean, standard deviation, minimum, maximum values, median and the level of significance was set at $P<0.05$. For the multiple comparison TukeyHSD test was used.

\section{Results}

Chemical analysis of BTM samples determined the mean iodine concentration of $135.95 \mu \mathrm{g} / \mathrm{l}$ but the values varied from $40.46 \mu \mathrm{g} / \mathrm{l}$ to $216.34 \mu \mathrm{g} / \mathrm{l}$, (Table 1 ). When considering milk samples from conventional (136.55 $\mu \mathrm{g} / \mathrm{l} \pm 42.91)$ and organic $(119.29 \mu \mathrm{g} / 1 \pm 40.37)$ dairy farms no apparent difference was detected (Fig. 1). In our research we also compared iodine concentration in milk from different herd-sized conventional farms. Low mean iodine content of $116.76 \pm 46.29 \mu \mathrm{g} / \mathrm{l}$ was determined in raw milk from small dairy farms (15-90 cows) and no significant difference from the samples originating from medium dairy farms (180-407), which was $112.92 \pm 94.74 \mu \mathrm{g} / \mathrm{l}$. The lowest values in small and medium dairy farms were very low, at the level of $45.30 \mu \mathrm{g} / \mathrm{l}$ and $40.46 \mu \mathrm{g} / 1$, respectively. Iodine content variability was higher in milk samples from medium dairy farms. On large dairy farms, the mean iodine concentration in BTM samples was $173.70 \pm 35.42 \mu \mathrm{g} / \mathrm{l}$, i.e. significantly higher than the values on small dairy farms $(P \leq 0.05)$.

Table 1. Milk iodine concentrations $(\mu \mathrm{g} / \mathrm{l})$ in bovine bulk milk tank samples.

\begin{tabular}{lccccc}
\hline \multicolumn{5}{c}{ Type of dairy farm } \\
& Small conventional & Medium conventional & Large conventional & Organic & Conventional \\
\hline Mean & $116.76^{\mathrm{a}}$ & 112.92 & $173.70^{\mathrm{a}}$ & 119.29 & 136.55 \\
SD & 46.29 & 94.74 & 35.42 & 40.37 & 42.91 \\
SEM & 11.95 & 24.46 & 9.14 & 10.42 & 15.19 \\
Median & 118.00 & 112.92 & 166.05 & 135.48 & 132.32 \\
Max & 199.56 & 174.59 & 216.34 & 203.14 & 216.34 \\
Min & 45.30 & 40.46 & 89.00 & 60.00 & 40.46 \\
\hline
\end{tabular}

Numbers with the same superscript (a) differ at $(P \leq 0.05)$

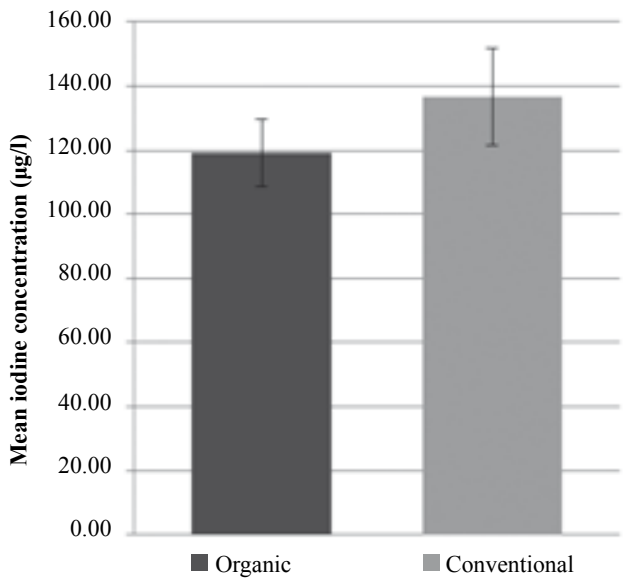

Fig. 1. Milk iodine concentrations $(\mu \mathrm{g} / \mathrm{l})$ in bovine bulk milk tank samples from organic and conventional dairy farms $(\mathrm{X} \pm \mathrm{SEM})$ 


\section{Discussion}

Our results correspond with the results described in the study of Kavřík et al. (2013), however, they reported higher values in both types of breeding (conventional $303 \mu \mathrm{g} / \mathrm{l}$, organic $253 \mu \mathrm{g} / \mathrm{l}$ ). Lower milk iodine concentration in organic milk samples was recorded by other authors, the differences in milk samples from conventional farms were higher and reached the range of 31.8-42.1\% (Dahl et al. 2003; Bath et al. 2011; ̌̌ehůřrková et al. 2013). The philosophy of organic farming restricts using mineral additives and higher goitrogens in feeding, i.e. cyanogenic glycosides, which lower iodine utilisation in the dairy cow's organism and consequently decrease iodine transportation to the mammary gland, needs to be considered. The entire iodine content is, of course, influenced by many factors beside the diet, such as the season, geographical region, stage of lactation, and using iodine teat dips and sanitizers (Norouzian and Azizi 2013). Our study did not consider the pasture locality on the represented farms. According to Trávníček et al. (2006) the iodine content in soil highly correlates with the iodine content in plants on the pasture. The meadow vegetation in most regions of the Czech Republic is poor in iodine content; the reported soil iodine value was $0.97 \pm 0.27 \mathrm{mg} / \mathrm{kg}$ in Jeseník, and $5.11 \pm$ $0.65 \mathrm{mg} / \mathrm{kg}$ in Šumava.

The determined values of iodine content in raw milk samples in our study are considerably lower than those reported in earlier studies of milk from the Czech Republic. In 2003, the mean concentration was $310 \mu \mathrm{g} / \mathrm{l}$; in 2010 the mean iodine concentration reached $490 \mu \mathrm{g} / \mathrm{l}$; and in 2012 the mean concentration was decreasing to the value of $360 \mu \mathrm{g} / \mathrm{l}$. On small dairy farms in the western region of the Czech Republic - Šumava foothills, which do not practice iodine supplementation, iodine concentration of only $80 \mu \mathrm{g} / \mathrm{l}$ was observed in milk (Kroupová et al. 2013). From a complex view, in our study the value determined in milk from large conventional dairy farms was in the optimum reference range for iodine concentration, which was calculated to $100-200 \mu \mathrm{g} / \mathrm{l}$ in raw milk (optimum estimation from the viewpoint of dietary exposure corresponding to the EU Regulation of $200 \mu \mathrm{g} / \mathrm{l}$ ) (Ř ehůr̆ková and Ruprich 2013). In our study, all the large dairy farms added brewers' grain into the diet regularly and the pasture was not available throughout the year. Brewers' grain is currently added to daily diets as a good source of proteins. The iodine content in brewers' grain is as low as $0.08 \mathrm{mg} / \mathrm{kg}$, corresponding to $0.4 \mathrm{mg}$ in the basal daily diet. No studies are available for the research question of how brewers' grain can influence the iodine content in milk.

In some cases, iodophores used for teat disinfection after milking can cause higher iodine concentration in milk obtained from these dairy farms. The study by Borucki Castro et al. (2012) focused on the influence of pre- and post-milking disinfecting, and reported that this treatment did not have any influence on the iodine content in milk. On the other hand, Flachowsky et al. (2007) and Galton (2004) found that post dipping by using iodine concentration in the range of $0.3-0.5 \%$ significantly increased milk iodine concentration by $33 \%$ and $45 \%$, respectively. In our study, post milking iodophor disinfectants were used on each dairy farm.

The mean iodine content in raw milk from small and medium conventional dairy farms corresponds with that from organic farms. The dairy cows were on pasture for half a year. The management on small and medium dairy farms is comparable with organic farming in our study. Our results correspond with those of Bath (2011) who detected significantly lower concentration in the milk from organic dairy farms, over $40 \%$ lower than in conventional farming.

The analysis of bulk milk tank samples in our study showed the variability of milk iodine content, and that the situation is changing dynamically. Based on the results it is obvious that large dairy farms have better management of milk iodine content, and the iodine 
content variability is the lowest, only $35.42 \mu \mathrm{g} / 1$, and is within the optimal reference range for milk. In a follow-up study, it will be necessary to evaluate the correlation between the iodine milk content and the pasture area. We can conclude that the variability of iodine concentration and the determined lower values compared to previous years, are reflecting the situation of dairy farms management and the character of farms involved in this study.

\section{Acknowledgement}

This study was supported by the Ministry of Agriculture in the Czech Republic, NAZV KUS QJ1230044.

\section{References}

Bath SC, Button S, Rayman MP 2011: Iodine concentration of organic and conventional milk: implication for iodine intake. Br J Nutr 107: 1-6

Borucki Castro SI, Berthiaume R, Robichaud A, Lacasse P 2012: Effects of iodine intake and teat dipping practices on milk iodine concentrations in dairy cows. J Dairy Sci 95: 213-220

Commission Regulation No. 1459/2005/EC of the Commission of the European Communities of 8 September 2005 amending the conditions for authorisation of a number of feed additives belonging to the group of trace elements. OJ L 238, 9 September 2005, pp. 8-10

Dahl L, Opsahl JA, Mitzer HM, Julshamn K 2003: Iodine concentration in Norwegian milk and dairy products. Br J Nutr 90: 679-685

Flachowsky G, Schone F, Leiterer M, Bemman D, Spolders M, Lebzien P 2007: Influence of an iodine depletion period and teat dipping in the iodine concentration of serum and milk of cows. J Anim Feed Sci 16: 18-25

Galton DM 2004: Effects of an automatic postmilking teat dipping system on new intra mammary infections and iodine in milk. J Dairy Sci 87: 18-25

Kavř́k R, Paskerová H, Rehưřková I, Ruprich J 2013: Dynamics of seasonal variation of iodine content in various types of milk available to consumers (in Czech). In Sborník X. konference u príležitosti Dne jódu: Zásobení jódem jako prevence tyreopatií a zdroje dietární expozice. České Budějovice, 48-51

Kroupová V, Trávníček J, Staňková M, Richterová J, Dušová H 2013: Dynamics of iodine concentration in bulk milk in the Czech Republic (in Czech). In Sborník X. konference u př́ležitosti Dne jódu: Zásobení jódem jako prevence tyreopatií a zdroje dietární expozice. České Budějovice, 32-33

Kursa J, Herzig I, Trávníček J, Kroupová V 2005: Milk as a food source of iodine for human consumption in the Czech Republic. Acta Vet Brno 74: 255-264

Norouzian MA, Azizi F 2013: Factors affecting iodine content in dairy cow's milk - a review. Eur J Food Res \& Rev 3: 63-73

Řehưřková I, Ruprich J 2013: Dietary supply of iodine to Czech population and its most important sources (in Czech). In Sborník X. konference u př́ležitosti Dne jódu: Zásobení jódem jako prevence tyreopatií a zdroje dietární expozice. České Budějovice, 13-19

Ryšavá L, Kříž J 2013: Prevention of iodine deficit in the Czech Republic - history and current situation (in Czech). In Sborník X. konference u př́ležitosti Dne jódu: Zásobení jódem jako prevence tyreopatií a zdroje dietární expozice. České Budějovice, 6-8

Trávníček J, Herzig I, Kursa J, Kroupová V, Navrátilová M 2006: Iodine content in raw milk. Vet Med 51: 448-453

Zamrazil V 2013: Risks from excessive iodine intake (in Czech). In Sborník X. konference u př́ležitosti Dne jódu: Zásobení jódem jako prevence tyreopatií a zdroje dietární expozice. České Budějovice, 10-12 